\title{
Study of Active and Fossil Hydrothermal Systems in Ijen Caldera Complex and Merubetiri Mountains, East Java
}

\author{
Mardhiawan Tri Susetyono and Lucas Donny Setijadji \\ Department of Geological Engineering, Faculty of Engineering \\ Universitas Gadjah Mada, Yogyakarta, Indonesia \\ *Corresponding author: 21stmardhiawan@gmail.com
}

Article received: 4 December 2020, revised: 15 January 2021, accepted: 15 June 2021

DOI: $10.51835 /$ ijeg.2021.1.1.340

\begin{abstract}
Ore deposits formed at subduction zone are associated with magmatism activities that are represented by volcanic activities at the surface. In the Eastern Sunda Arc, one of active volcanic activity can be found in Ijen Caldera Complex. The complex has hydrothermal volcanic manifestations with a very acidic $\mathrm{pH}$. Meanwhile in the south of Ijen Complex, there is ancient volcanic complex called Merubetiri Mountains that is proven to be well-mineralized at Tumpangpitu as high sulfidation and porphyry-style mineralizations. An understanding of hydrothermal activity and volcanic landforms in active volcanic systems can be used as a powerful tool to understanding hydrothermal systems. This paper presents the distinction between active hydrothermal systems and fossil hydrothermal systems as an exploration's tool in ancient volcanic systems. The method used in this study is remote sensing with focus on volcanic landforms, geological structures, and distribution of alteration minerals. ASTER satellite imagery, Landsat 8 satellite imagery, and DEMNAS are used in this study. ASTER and Landsat 8 images are processed with Principle Component Analysis (PCA) and Direct Principle Component (DPC) methods to determine the distribution of alteration minerals that are associated with propylithic, argillic, advanced argillic, and silisic alterations. Semi-quantitative method is used to identify geological structures by automatic lineament detection. Meanwhile, qualitative method is used by manual lineaments delineation on the DEM imagery. Delineations of volcanic landforms in active and ancient volcanic complex use semi-quantitative methods include ridge lineaments and flow pattern. Then, volcanic landform is manually delineated by determining the distribution pattern of ridges, flow pattern, morphological texture, and cross-cutting relationship of volcanic products as a key in determine the eruption centers. The results show a relationship between volcanic distribution and the main stresses in the Ijen Caldera Complex with NE-SW direction, which is represented by the elliptic and elongation of volcanic depression zone, monogenetic volcano, and intrusion distribution. Geological structures that are found in the Ijen Caldera Complex show E-W and NE-SW directions. Meanwhile, Merubetiri complex shows E-W, NW-SE, and N-S structural direction patterns. The distribution of alteration minerals associated with silisic, argillic, and advance argillic in the Ijen Caldera Complex are found in the central zone of stratovolcano, intra-caldera zone, and structural zone that intersects the caldera. This shows that active hydrothermal system is related to volcanic activity and geological structures. Meanwhile, in the Merubetiri complex, alteration minerals are associated with the eruption centers, diorite/granodiorite intrusions, and NW-SE strike slip fault. The understandings of volcanic setting and volcanic landforms are very important in the early stages of exploration to determine the prospect of mineral deposits related to hydrothermal system.
\end{abstract}

Keywords: Ijen, Merubitiri, hydrothermal, ASTER, Landsat 8.

\section{INTRODUCTION}

Sulfide mineral deposits are one of the sulfur magmatic system manifestations in a subduction zone (Stern, 2015). Some deposits are associated with volcanic intrusions.
Hydrothermal fluids become metal carrier agents in mineral deposits. This fluid circulation passes through various rocks and altered the rocks. Hydrothermal ore deposits are associated with altered rocks and this will 
be a host of hydrothermal mineralization. Besides, metals can also be precipitated by the release of magmatic degassing from metal-rich volatiles (Stern, 2015).

Metal deposit is closely related to the magmatic system with surface manifestations shown by different volcanic landforms such as stratovolcano, flow dome complex, caldera, and maar. The central zone of stratovolcanoes is usually associated with copper porphyry deposits and metal veins, which are represented by geothermal/hydrothermal systems in the stratovolcano setting. Metal and breccia $\mathrm{Cu}$ $\mathrm{Pb}-\mathrm{Zn}-\mathrm{Ag}$ veins are the results of emplacement in flow dome complex which is analogous to the geothermal system as a hot spring sinter. Also, metal veins are associated with fractures around the caldera (Sillitoe and Bonham, 1984). Understanding the volcanic system will be very helpful in understanding the hydrothermal system associated with mineralization in the magmatic arc of the subduction zone. Hedenquist (1995) introduced two volcanic systems associated with epithermal mineralization. First, a geothermal system that is controlled by fluids with a neutral $\mathrm{pH}$ and low temperature, with its considerable distance from the magma source. The second is a hydrothermal volcanic system that is controlled by hot and acid fluids; this system develops in the proximal to volcanic vent the discharge of magmatic vapor to the surface.

Magmatic and volcanic evolution of the Sunda Arc is migrating to the north or towards the back-arc of Java subduction during the Tertiary (Setijadji et al., 2006). The representation of magmatic shift can be seen on the surface where the southern part is a mountain range of the remaining Tertiary magmatic arc. On the other hand, the middle of Java Island is a range of Quaternary volcanoes. This research is located in the Ijen Caldera Complex as a representation of the active hydrothermal system and the Merubetiri Mountains as a representation of the fossil hydrothermal system. This research location can be seen in Figure 1.

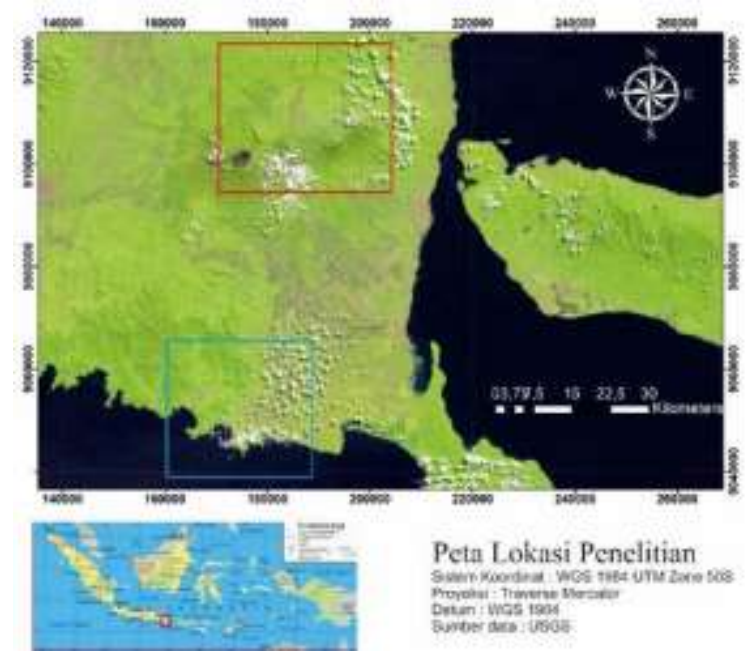

Figure 1. Research location

Ijen Crater in the Ijen Caldera Complex is a hydrothermal volcanic system that is still active and it has characteristics a very acidic fluid with a $\mathrm{pH}$ between 0 and 2 and solfatara manifestation. There is high sulfidation mineralization that is formed directly from the condensation of magmatic gas in Ijen Crater (Scher, 2013). Meanwhile, the Merubetiri Mountains are a Tertiary volcanic remnant complex with a fossil hydrothermal system that has been proven by the discovery of epithermal and porphyry mineralization in Tumpangpitu (Harrison et al., 2018).

Understanding the hydrothermal systems, both the active magmatism arc and residual magmatism arc can be done by understanding the existing volcanic setting system and also the hydrothermal system that is manifested by surface altered rocks due to hydrothermal fluid circulation. Mineral mapping using remote sensing has been widely carried out around the world at regional and local scales 
(Sabins, 1999). In this study, the remote sensing method is used with a focus on the distribution of hydrothermal alteration minerals, volcanic centers, and geological structures that exist in the Ijen Caldera Complex and the Merubetiri Mountains to obtain an overview of the active hydrothermal system and the fossil hydrothermal system in the Sunda Arc.

\section{METHODOLOGY}

The method used in this research is remote sensing observation using satellite imagery and Digital Elevation Model (DEM) imagery. Satellite images used are Landsat 8 imagery and ASTER image that are downloaded from the USGS website: earthexplorer.usgs.gov. DEM images used are DEMNAS that are downloaded from the website http://tides.big.go.id/. The other data is the spectral library data that is used as the main reference for interpretation. There are several stages in satellite image analysis: preprocessing, processing, classification, and visualization stages.

In the pre-processing stage, the atmospheric correction is carried out with FLAASH (Fast Line-of-sight Atmospheric Analysis of Spectral Hypercubes) correction and masking to select areas covered by cloud and water. in the case, the central part of the crater which consists of water and seawater from the Indian Ocean will be masked to remove unwanted data because it can be contaminated with the data distribution after a threshold value is applied.

At the processing stage, the PCA (Principal Component Analysis) method is used, which is a technique for using image datasets that make it easier to interpret uncorrelated variables that represent most of the information in the original dataset. this method is an image enhancement or sharpening technique that transforms the original correlated image data into a set of uncorrelated variables called the Principle Component Analysis (PCA) (Jensen, 2015). The input band on PCA refers to the spectral pattern of the object to be searched for as an example described in Figure 2. Besides, the PCA method, the Directed Principle Component Analysis (DPCA) method is also used where band ratio components are used as data which is processed where the band components are used. The first band ratio is used for mineral occurrences and the second band ratio is vegetation index.

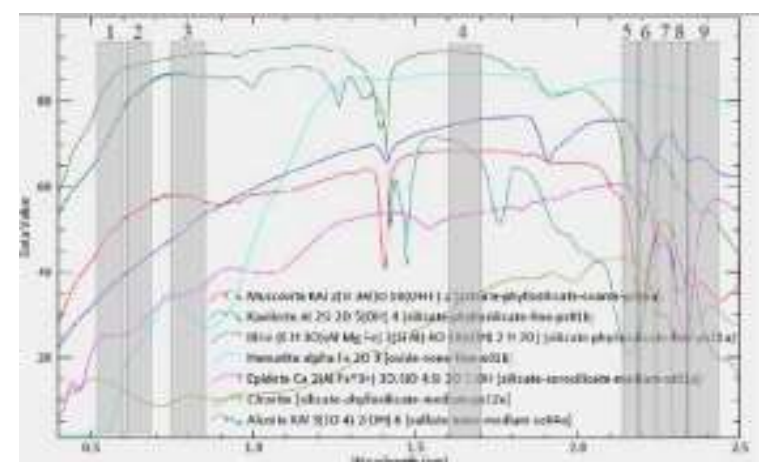

Figure 2. USGS Spectral Library on several minerals displayed on the ASTER VNIR and SWIR bands.

The overlapping of the image band with mineral spectral will make it easier to determine the high absorption and high reflectance characteristics in each band. In this way, several band choices can be obtained according to their characteristics in this mineral mapping at the research location. The selected band in the ASTER image can be seen in Table 1. Meanwhile, the selected band in the Landsat 8 image can be seen in Table 2 and the DPC analysis of Landsat images can be seen in Table 3 . 
Table 1. Band selection on the PCA analysis of ASTER images

\begin{tabular}{lcc}
\hline \multirow{2}{*}{ Mineral } & \multicolumn{2}{c}{ Reflectance } \\
\cline { 2 - 3 } Kaolinite & High & Low \\
\hline \multirow{3}{*}{ Alunite } & Band 3 & Band 6 \\
& Band 7 & Band 9 \\
Ilite & Band 4 & Band 5 \\
& Band 7 & Band 6 \\
Muscovite & Band 4 & Band 6 \\
& Band 7 & Band 8 \\
Chlorite & Band 4 & Band 6 \\
& Band 7 & Band 9 \\
Epidote & Band 4 & Band 2 \\
& Band 5 & Band 8 \\
Hematite & Band 4 & Band 1 \\
& Band 5 & Band 8 \\
& Band 5 & Band 3 \\
& Band 8 & Band 6 \\
\hline
\end{tabular}

Table 2. Band selection on the PCA analysis of Landsat 8 images

\begin{tabular}{lll}
\hline \multirow{2}{*}{ Mineral } & \multicolumn{2}{c}{ Reflectance } \\
\cline { 2 - 3 } Chlorite & Band 3 & Low \\
& Band 6 & Band 1 \\
Epidote & Band 6 & Band 1 \\
& & Band 2 \\
Alunite & Band 3 & Band 7 \\
& Band 5 & \\
Muscovite & Band 6 & Band 1 \\
& & Band 7 \\
Kaolinite & Band 3 & Band 7 \\
& Band 6 & \\
Hematite & Band 5 & Band 2 \\
& Band 6 & \\
\hline
\end{tabular}

Table 3. Band configuration in DPCA analysis of Landsat 8 imagery (Salamba et al, 2019)

\begin{tabular}{lcl}
\hline \multirow{2}{*}{ Mineral } & \multicolumn{2}{c}{ Band ratio for DPCA on Landsat 8 } \\
\cline { 2 - 3 } & Vegetation & \multicolumn{1}{c}{ Mineral } \\
\hline Silica & Band 3/Band 4 & Band 7/Band 2 \\
Alunite & Band 5/Band 2 & Band 6/Band 7 \\
Kaolinite & Band 5/Band 4 & Band 6/Band 7 \\
Chlorite & Band 5/Band 3 & Band 6/ Band 7 \\
Epidote & Band 3/Band 4 & Band 6/Band 2 \\
\hline
\end{tabular}

After that, PC was selected based on the influence significance of the band on each $\mathrm{PC}$, seen in the eigenvector value where the value away from zero means that the band has a high significance effect on PC. Then, The selected PC is subjected to threshold processing with a threshold value of $99 \%$ to make it more confident.

In analyzing the geological structure, two methods are used, namely qualitative methods and semi-quantitative methods. The qualitative method used is the manual delineation of the DEM image. Meanwhile, the semi-quantitative method was used with automatic lineament extraction analysis on the PCI Geomatica software. The parameters used are in Table 4.

Lithology and volcanic landforms interpretation is carried out by observing morphology, regional geological maps, and existing research data. An automatic ridge is used to assist the interpretation of volcanic centers in addition to observing the roughness of the morphological texture based on DEM images.

Table 4. Parameters used in automatic lineament extraction (Javhar et al, 2019)

\begin{tabular}{cccc}
\hline & \multicolumn{3}{c}{ Value } \\
\cline { 2 - 4 } Aspect & Default & Proposed & Used \\
\cline { 2 - 4 } RADI & 10 & $3-8$ & 8 \\
GTHR & 100 & $10-70$ & 60 \\
LTHR & 30 & $10-50$ & 20 \\
FTHR & 3 & $2-5$ & 3 \\
ATHR & 30 & $3-20$ & 15 \\
DTHR & 20 & $10-50$ & 20 \\
\hline
\end{tabular}

\section{RESULTS AND DISCUSSION}

\section{Alteration Mineral Mapping}

In the processing of the ASTER image, two different images were used to identify alteration minerals in the Ijen Caldera Complex, and three different images were used to identify alteration minerals in the Merubetiri Mountains. This was done because the ASTER image could not cover the entire area in the two study areas. Processing is done individually and the results of these 
alteration mappings are combined in the visualization stage.

The selection of PC per individual mineral was seen from the significance value of the band in each PC and adjusted to the spectral characteristics of the mineral. For example, in the mapping of kaolinite minerals in the Merubetiri Mountains, the PCA results from the selected bands can be seen in Table 5. Based on their spectral characteristics, kaolinite mineral has high absorption characteristics in band 6 and band 9 and high reflectance in band 3 and band 7. Based on the eigenvector value PCA analysis results, PC 3 has a high significance effect on band 3 and low on bands 6 and 9. so, PC 3 is used to analyze kaolinite mineral at the study site. A positive eigenvector value shows that the kaolinite mineral will be shown as a bright area in Figure 3.

Table 5 PCA selection for kaolinite mineral in ASTER image processing

\begin{tabular}{ccccc}
\hline $\mathbf{P C}$ & $\mathbf{B ~ 3} \uparrow$ & $\mathbf{B ~ 6} \downarrow$ & $\mathbf{B ~ 7} \uparrow$ & $\mathbf{B ~ 9} \downarrow$ \\
\hline 1 & 0.224 & 0.538 & 0.554 & 0.593 \\
\hline 2 & -0.224 & 0.57 & 0.31 & -0.72 \\
\hline 3 & 0.947 & -0.021 & -0.021 & -0.319 \\
\hline 4 & 0.044 & 0.621 & -0.775 & 0.14 \\
\hline
\end{tabular}

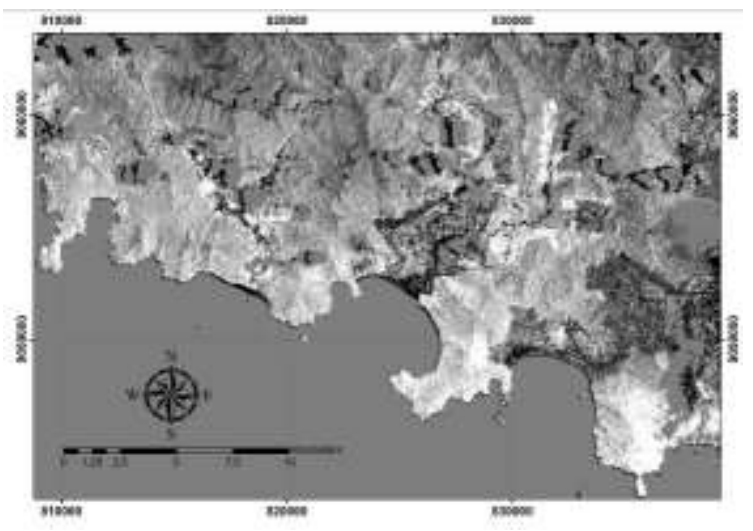

Figure 3. ASTER image processing results in the presence of kaolinite minerals in the southeast of the Merubetiri Mountains. Tumpangpitu is one of the areas that are shown as a bright color.

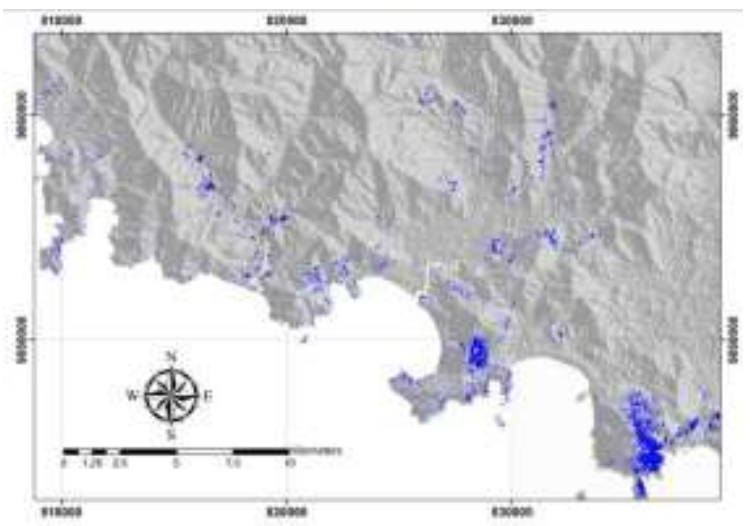

Figure 4. The kaolinite mineral distribution with a threshold of $99 \%$ and overlaid on the hillshade map

By doing the same with the other ASTER images, we can get the distribution of the associated alteration minerals based on the type of alteration as shown in Figure 5 for the Ijen Caldera Complex. The argillic alteration on the map is represented by the presence of kaolinite, illite, and alunite minerals. The phyllic alteration on the map is represented by the presence of muscovite minerals. Propylitic alteration is represented by the presence of chlorite and epidote minerals. 


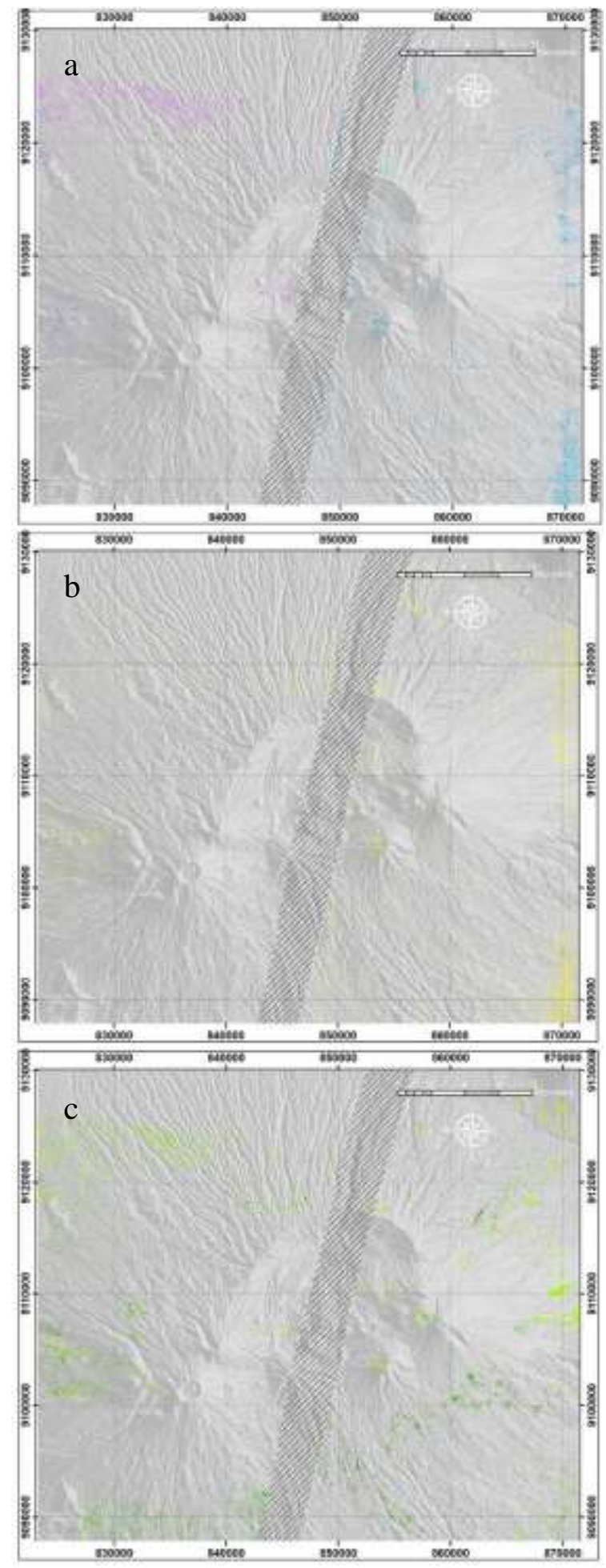

Figure 5. Map of the distribution of alteration minerals based on ASTER image analysis using the PCA method in the Ijen Caldera Complex. The map shows the distribution of minerals associated with argillic alteration (a), phyllic alteration (b), and propylitic alteration (c). The shaded area is an area without image data.
The distribution of alteration minerals based on ASTER image analysis on the Merubetiri Mountain is shown in Figure 6. In addition to ASTER image processing, Landsat 8 image processing is carried out as supporting data in mapping the alteration minerals in the two locations. The choice of Landsat 8 imagery is because it has a wide coverage and shorter temporal resolution so that more current data can be used with field conditions. ASTER images that can be used for mineral mapping are only images acquired before April 2008 and this does not apply to Landsat 8 imagery. The method used in Landsat 8 is the same as the processing for ASTER images.

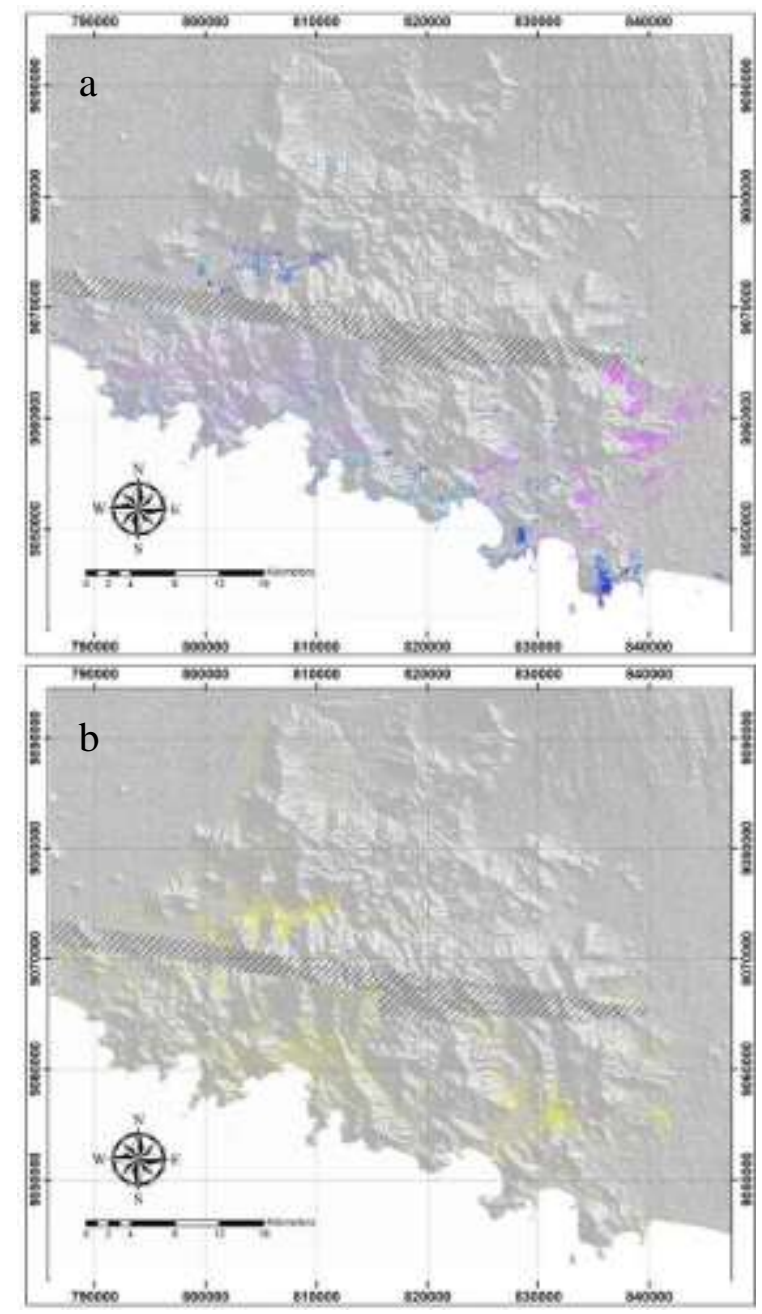




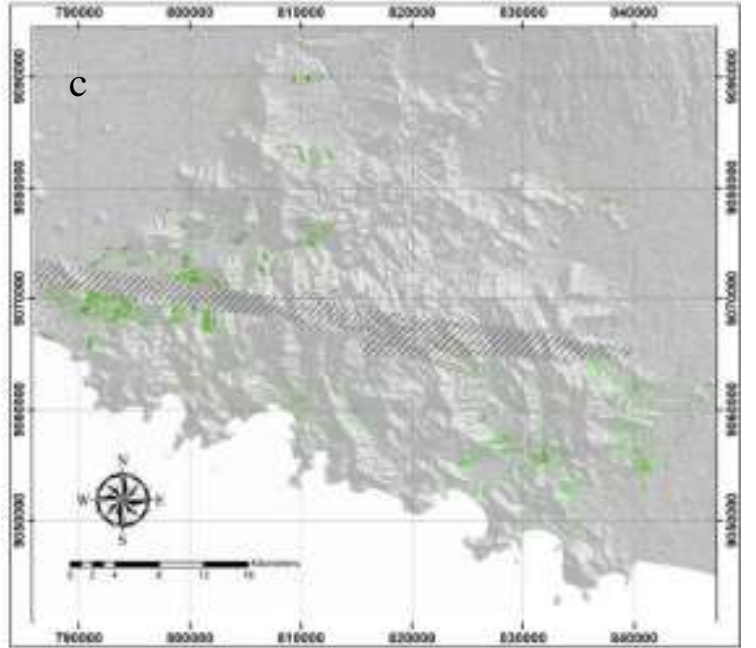

Figure 6. Map of the distribution of alteration minerals based on ASTER image analysis using the PCA method in the Merubetiri Mountains. The map shows the distribution of minerals associated with argillic alteration (a), phyllic alteration (b), and propylitic alteration (c). The shaded area is an area without image data

Mapping of minerals in the Ijen Caldera Complex can be seen in Figure 7 as a results of PCA method and Figure 8 as the results of DPCA method with the distribution of alteration minerals associated with argillic alteration, phyllic alteration, and propylitic alteration.

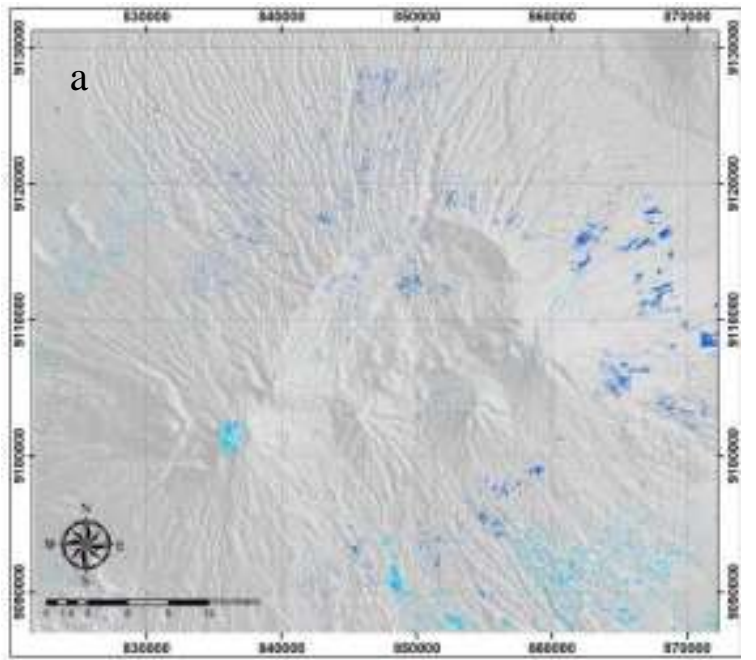

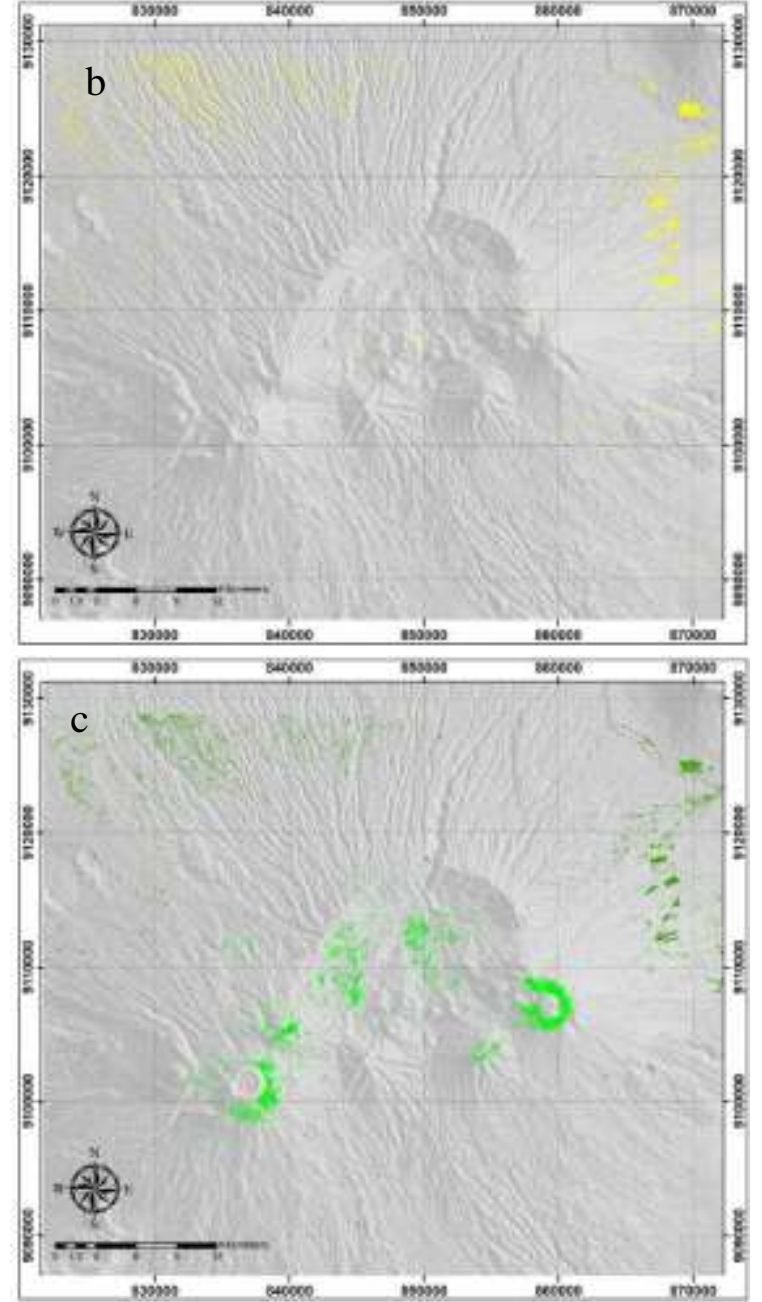

Figure 7. Map of the distribution of alteration minerals based on Landsat 8 image analysis using the PCA method in the Ijen Caldera Complex. The map shows the distribution of minerals associated with argillic alteration (a), phyllic alteration (b), and propylitic alteration $(\mathrm{c})$

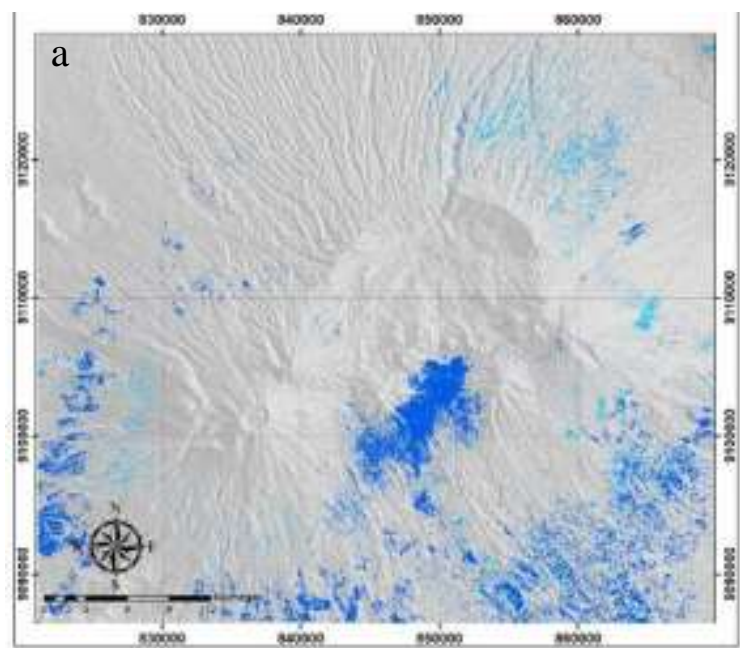



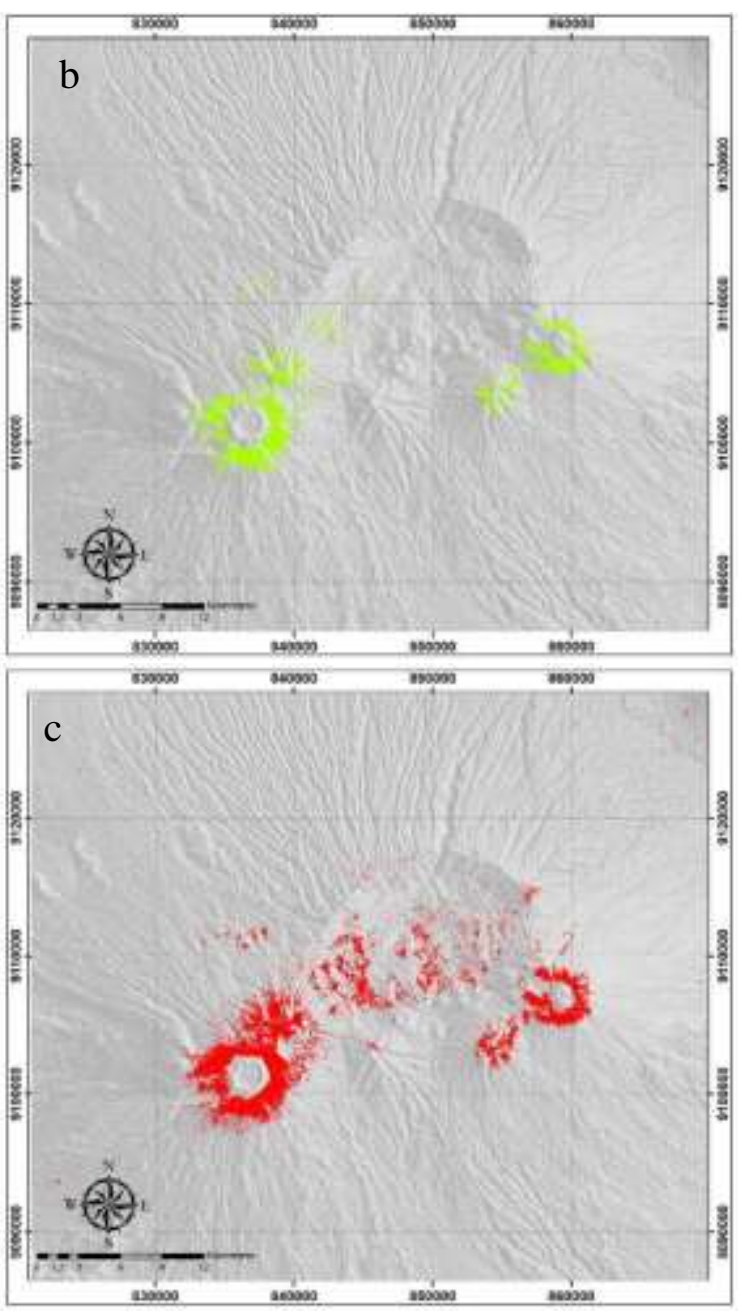

Figure 8. Map of the distribution of alteration minerals based on Landsat 8 image analysis using the DPCA method in the Ijen Caldera Complex. The map shows the distribution of minerals associated with argillic alteration (a), phyllic alteration (b), and silica alteration (c)

The distribution of alteration minerals based on ASTER image analysis on the Merubetiri Mountain is shown in Figure 9 as a results of PCA method and Figure 10 as the results of DPCA method.

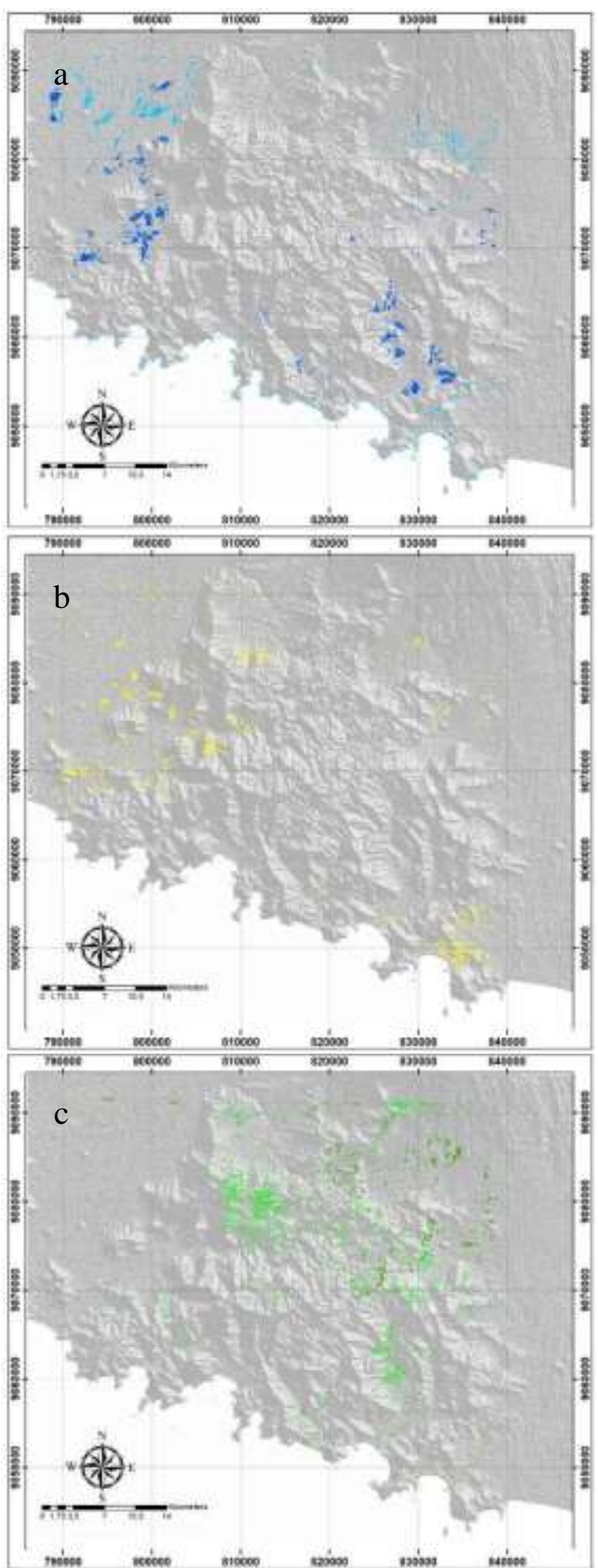

Figure 9. Map of the distribution of alteration minerals based on Landsat 8 image analysis using the PCA method in the Merubetiri Mountains. The map shows the distribution of minerals associated with argillic alteration (a), phyllic alteration (b), and propylitic alteration (c) 


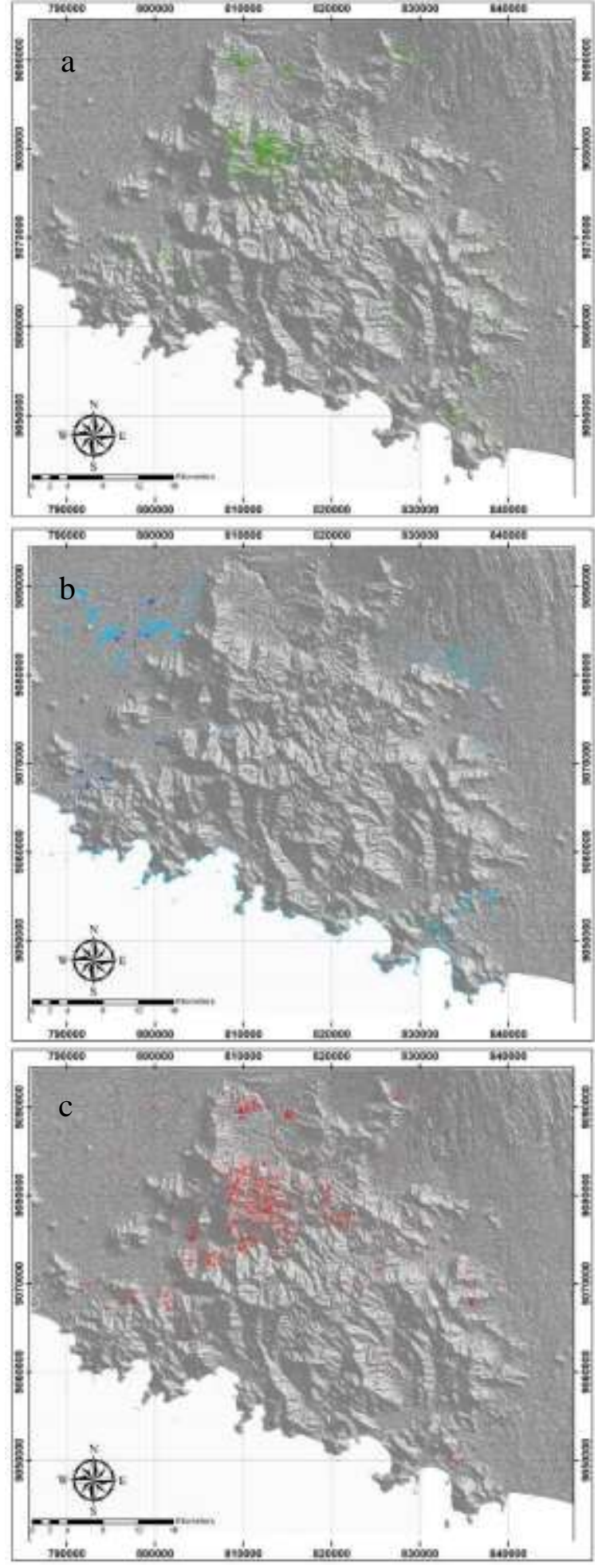

Figure 10. Map of the distribution of alteration minerals based on Landsat 8 image analysis using the DPCA method in the Merubetiri Mountains. The map shows the distribution of minerals associated with argillic alteration (a), phyllic alteration (b), and silica alteration $(\mathrm{c})$

\section{Lineament Analysis}

Lineament analysis is carried out by 2 methods, manual delineations and automatic lineament extraction using the computer software. The results of manual delineations can be seen in Figure 11. Meanwhile, the results of automatic lineament extraction can be seen in Figure 12.
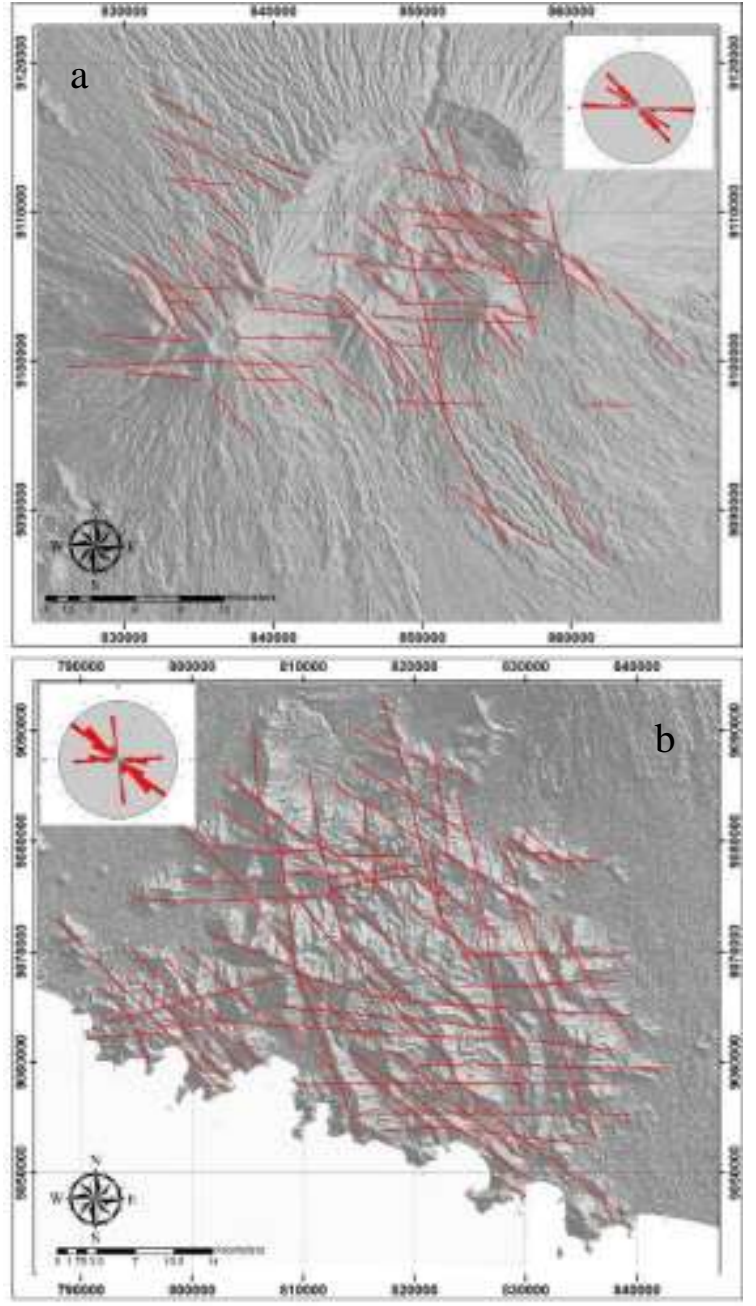

Figure 11. Manual delineation of Ijen Caldera Complex (a) and Merubetiri Mountains (b)

\section{Geological Interpretation}

By using regional geological maps and DEM imagery, geological interpretation is made to assist in understanding the existence of volcanic centers in Tertiary volcanic systems. Criteria used to make the zonation are ridge patterns, flow patterns, morphological textures, and intersecting 
relationships that can be reflected in morphology. Geological maps resulting from remote sensing interpretation are carried out by dividing the formation into subformations. Reinterpretation of geological maps will help in terms of understanding volcanic activity, especially in delineating

(a)

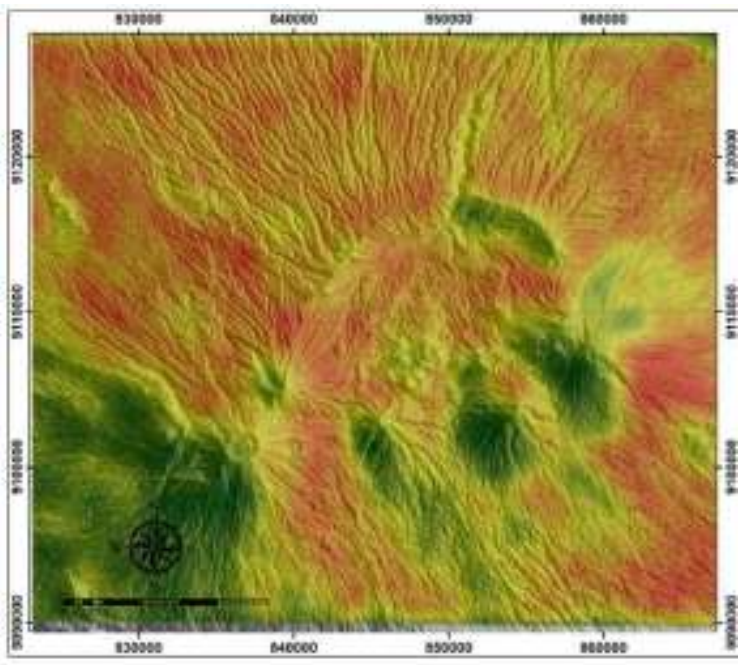

Figure 12. Line density based on automatic lineament extraction on Ijen Caldera Complex (a) and Merubetiri

Mountains (b)
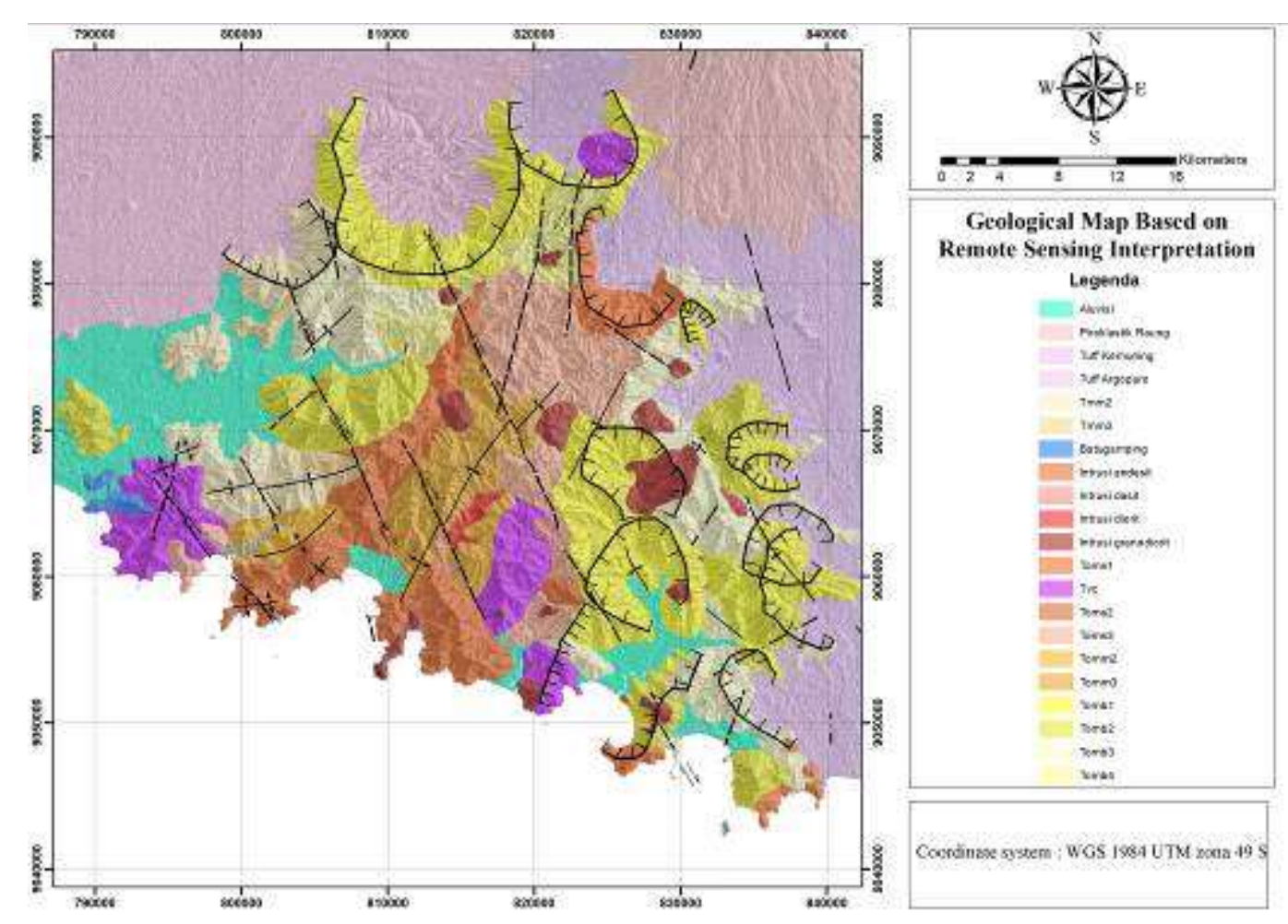

Figure 13. Geological map of Merubetiri Mountains based on remote sensing interpretation remnants of the Merubetiri Mountains. The geological map of the interpretation of the Merubetiri Mountains can be seen in Figure 13 and the interpretation of the volcanic centers can be seen in Figure 15. complex volcanic centers of the volcanic

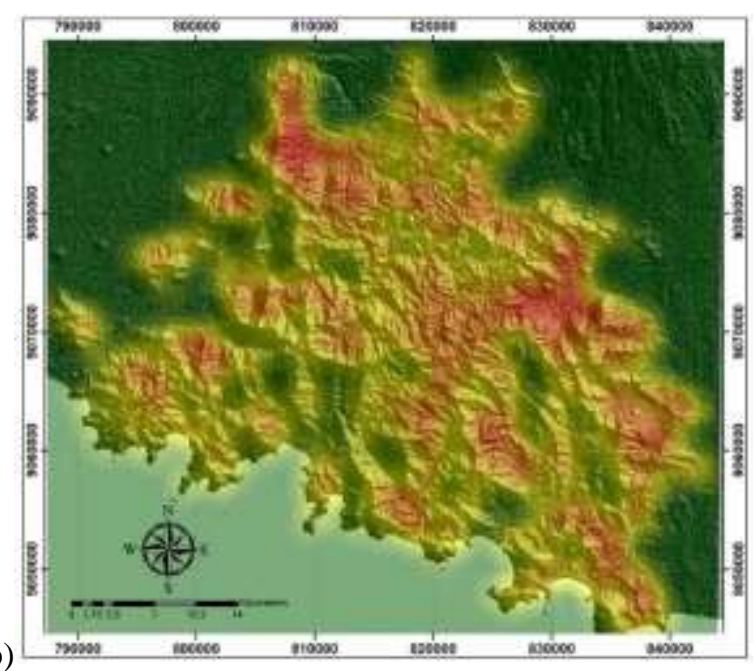


The Ijen Caldera Complex is a caldera complex with active volcanic activity. Based on morphological observations, the Ijen Caldera Complex is divided into rim caldera stratovolcano, intra-caldera, and caldera flank. Monogenetic volcanoes can be found in both stratovolcano and intra-caldera Ijen volcanoes. The Merubetiri Mountains are a complex of volcanic remnants in the south of the Ijen Caldera Complex. Based on image analysis and regional geological maps, it is identified that there are several remnant formations of volcanoes that are interpreted as volcanic centers such as volcanic cones, caldera, volcanic depressions, and intrusions (diorite, dacite, andesite, and granodiorite) (Figure 14 and Figure 15).

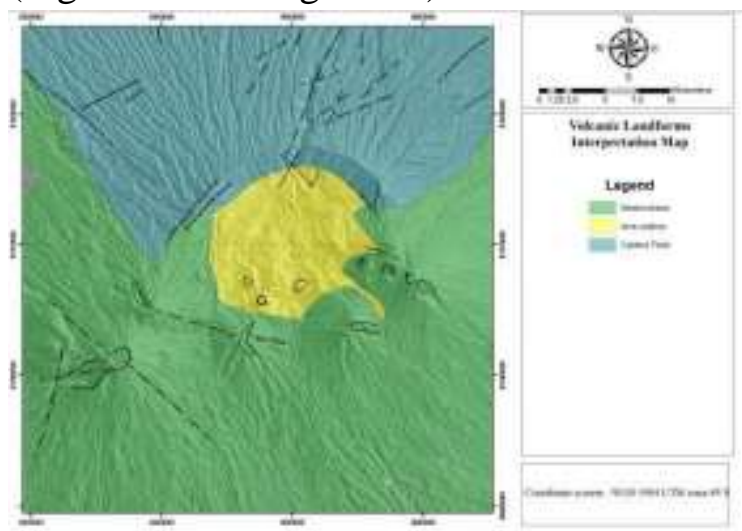

Figure 14. Volcanic center interpretation based on remote sensing method in Ijen Caldera Complex

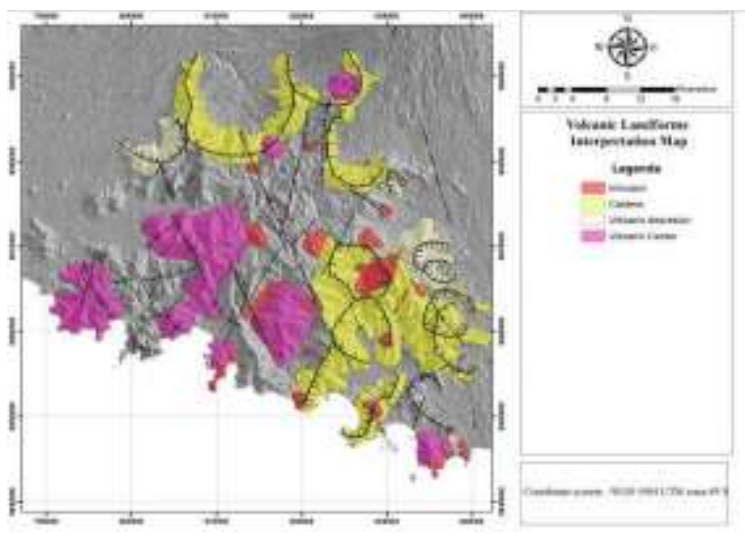

Figure 15. Volcanic center interpretation based on remote sensing method in Merubetiri Complex

Based on the manual delineations, it was found that the lineaments in the Ijen Caldera
Complex led to NW-SE and E-W (Figure 11a). it was also found a large structure leading to the NNE-SSW which intersects the Ijen Caldera. Regionally, in the Ijen Caldera Complex, the identified structures are volcanic depression and buried faults due to existing volcanic activity (Sidarto et al. 1993; Agustiyanto and Santosa, 1993) Whereas in the Merubetiri Mountains, structural lineaments have a dominant direction of $\mathrm{E}-\mathrm{W}$, NW-SE, and NNW-SSE (Figure 11b). Regionally, the structures found were shear faults with NW-SE and N-S directions and folds that led to NE-SW direction (Sapei et al., 1992; Achdan and Bachri, 1993). Based on the lineament density analysis, the Ijen Caldera Complex shows a high intensity with a tendency towards NW-SE and E-W (Figure 12a). The Merubetiri Mountains also show a tendency for a high-density pattern that leads to NW-SE, N-S, and E-W (Figure 12b). This result strengthens confidence in the manual delineation method. The density of these lineaments can also be used as a basis for showing how the morphological texture, where high density is showing a rough texture, and low density is showing a smooth morphological texture. This can also help in analyzing the eruption centers where according to Bronto (2013) the volcanic center shows a rougher texture than the surroundings.

Based on the satellite imagery analysis, it shows several areas of alteration mineral density. In the Ijen Caldera Complex, both the ASTER and Landsat 8 imagery shows the argillic alteration distribution is in the volcanic craters of the rim caldera stratovolcano, intra-caldera mainly on the major fault across the caldera, and also the caldera flank. The distribution of muscovite minerals as a representation of phyllic 
alteration is in the crater of rim caldera stratovolcano on ASTER image processing. Whereas the Landsat 8 image shows the intracaldera distribution on the large fault channel that intersects the caldera with the N-S and northern caldera flank. The distribution of epidote and chlorite minerals as a representation of propylitic alteration in the ASTER image is in the Ijen crater, intracaldera, and the outer of the Caldera flank. While, in the Landsat 8 image it shows the occurrence is in the proximal zone outside the crater of a stratovolcano, intra-caldera, and the caldera flank. In DPCA processing using Landsat 8 imagery, there is an additional concentration of silica in the intra-caldera and the outer part of the stratovolcano rim caldera.

In the Merubetiri Mountains, the presence of alteration minerals with argillic and phyllic types is located in the western and southern parts of the complex. while, in the landsat 8 imagery it is also found in the north of the complex. a high concentration of kaolinite was found in Tumpangpitu. Tumpangpitu is an area with highintermediate sulfidation epithermal and porphyry deposits. High sulfidation epithermal mineralization occurs in volcanic and volcanic rocks. There are 3 mineralization domains, namely zone $\mathrm{A}$, zone $\mathrm{B}$, and zone C (Figure 16) (Myaing et al, 2018) High- and intermediate- sulfidation $\mathrm{Au}-\mathrm{Ag} \pm \mathrm{Cu}$ is associated with advanced argillic alteration (part of the lithocap) overprinted by porphyry mineralization (Harrison et al, 2018). In Landsat 8 image processing, there is a bias of data with a high value in residential areas characterized by tight intensity and forming a pattern of human land-use. Similar to argillic and phyllic, propylitic alteration also shows its occurrence in the western and southeastern regions of the complex. However, the Landsat 8 imagery shows a significant alteration in the northern part of the complex, especially in DPCA processing; there are silica concentrations along with argillic and propylitic alterations.

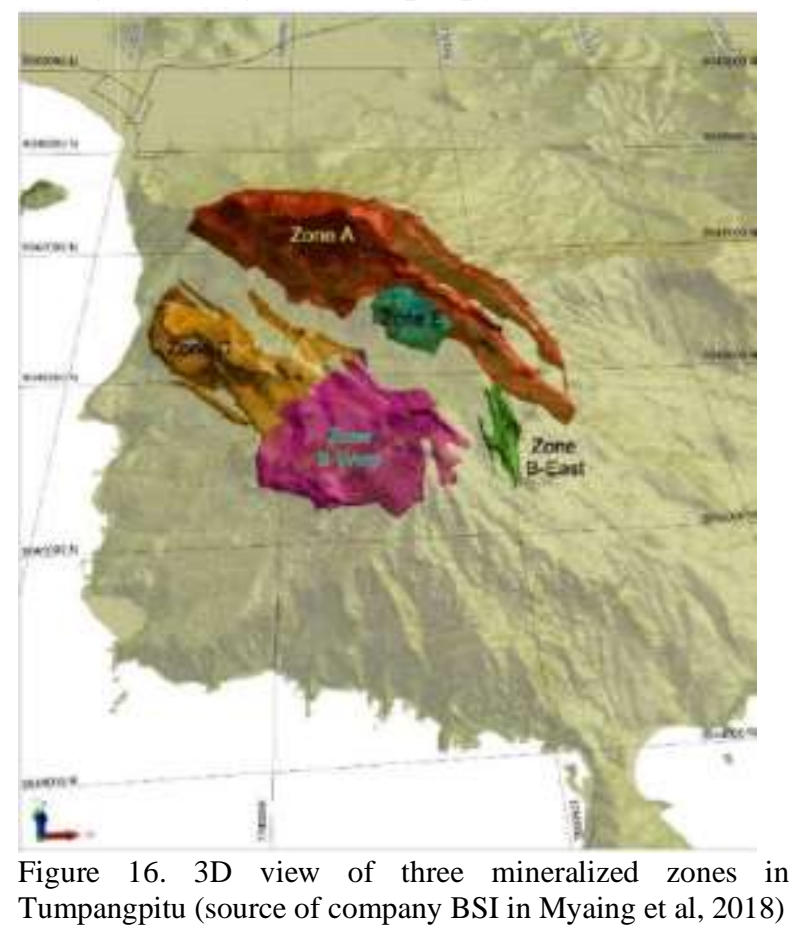

The Ijen crater area does not show significant clay mineral occurrence because the data is masked due to the water body to prevent contamination of the data. Based on data processing, the edge of the crater still shows the presence of these minerals. The presence of alteration minerals associated with argillic alteration in the Ijen crater corresponds to the activity of fumaroles in the Ijen crater (Figure 16). according to Scher et al (2013), a hydrothermal alteration found here is residual silica, alunite-pyrite, and dickite/kaolinite. Based on the evidence found, it was concluded that the development of high sulfidation epithermal mineralization was formed directly by magmatic gas condensed in the Ijen crater. 


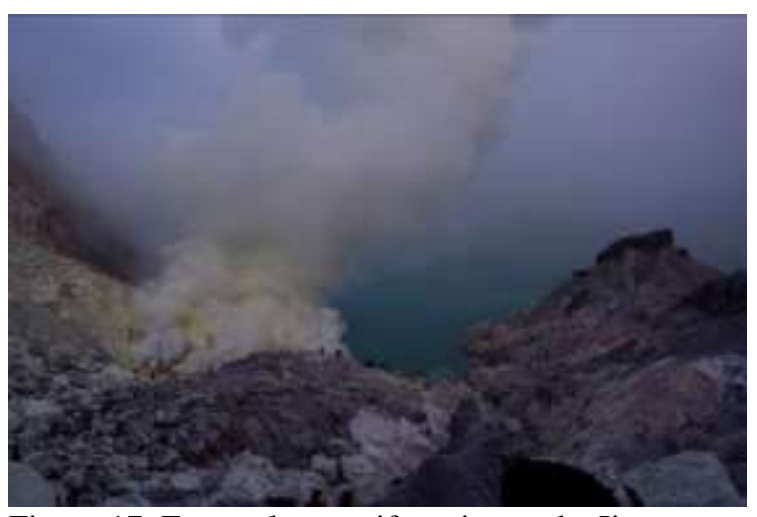

Figure 17. Fumaroles manifestation at the Ijen crater

The insignificant distribution of alteration minerals in Ijen Caldera Complex is caused by active volcanism so that the areas are covered by the young volcanic product, but it can be found at the manifestation of the geothermal system, the magmatic vapor discharge area is interpreted by the presence of advanced argillic alteration (Stimac et al. 2019). In the propylitic alteration analysis, the data obtained is quite high with a very wide distribution, this can happen because of the spectral identification is quite limited to the components of several bands causing data bias between the presence of these objects as an alteration mineral or not. Because the fewer bands are used, then the level of data accuracy will be decreased. In addition, the magmatism that develops in the Ijen Caldera Complex is also andesit-basaltic magmatism so that the bias in chlorite-epidote data processing can be caused by bias with this basaltic volcanism product. The distribution of alteration minerals also shows a quite interesting pattern in the intra-caldera where the minerals are distributed following the developing structure, especially the large fault structures that cut the caldera north-south. The main stress that develops in this complex is the northwest-southeast direction where this is also shown by the ellipses and elongation of volcanic depressions as well as the distribution of monogenetic volcanoes in the Ijen Caldera Complex.

The same thing is found in the Merubetiri Mountains. The distribution of alteration minerals corresponds to areas of volcanic centers resulting from remote sensing interpretation. In general, alteration minerals occupy the remaining volcanic cones, intrusions, and caldera features. In the caldera in the north of the Mountains, alteration minerals are concentrated in the south of the caldera which is thought to be a volcanic deconstructive zone that morphologically has a fairly high level of roughness compared to the surrounding area. The presence of argillic alteration minerals in Tumpangpitu shows a high enough intensity that can be used as validation in remote sensing alteration mapping, especially in Merubetiri Mountains.

The volcanic landforms that develop in the two complexes are mostly caldera features in both the Ijen Caldera Complex and the Merubetri Mountains. Caldera evolution has three stages: pre-collapse, collapse, and reactivation (Sigurdsson, 2000). In this reactivation or post-collapse stage, volcanic faults in the caldera system will form, make it easier for magma to rise and produce volcanic activity, especially on the rim of the caldera and inside the caldera. In addition, this fault also provides a path for circulating fluids. The hydrothermal system will be well-developed; during this period mineralization often occurs, especially in the caldera complex. Morphologically, the Ijen Caldera Complex is on this phase, as indicated by the stratovolcano activity that develops on the edge of the southern caldera. The manifestation of fumaroles and very acidic craters, especially in the Ijen crater, and the results of image processing that are in accordance with the density can be used as 
validation of the image processing that has been done.

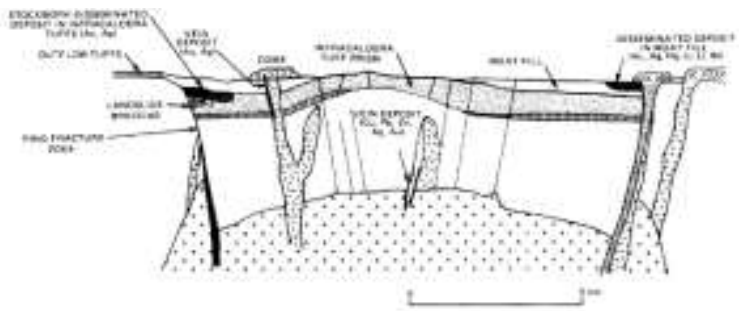

Figure 18. Idealized model of possible ore deposit type related to caldera setting (Sillitoe and Bonham, 1984)

Mineral deposits associated with the caldera settings are modeled by Silitoe and Bonham (1984) in Figure 18. Some caldera is barren, especially in the caldera that did not undergo resurgence. In the caldera that has mineralization has a spatial correlation to the ring fracture zone. copper porphyry deposits are not proven to be in the caldera settings, but it is reported that several mineral deposits are in the caldera ring fracture zone, especially on the summit calderas which are directly related to the deeper central parts of stratovolcanoes. High sulfidation mineralization is associated with advanced argillic alteration at the highest levels of stratovolcano edifices (Silitoe and Bonham, 1983). High sulfidation epithermal deposits can form in the lithocap above the porphyry copper deposits. The alteration zone in the porphyry copper deposits begins with a barren area, the initial sodic-calcic potassic potential of the ore zone, chlorite-sericite, sericite, advanced argillic, and lithocap which may have a thickness of $>1 \mathrm{~km}$ if there is no significant erosion (Figure 19) (Sillitoe, 2010).

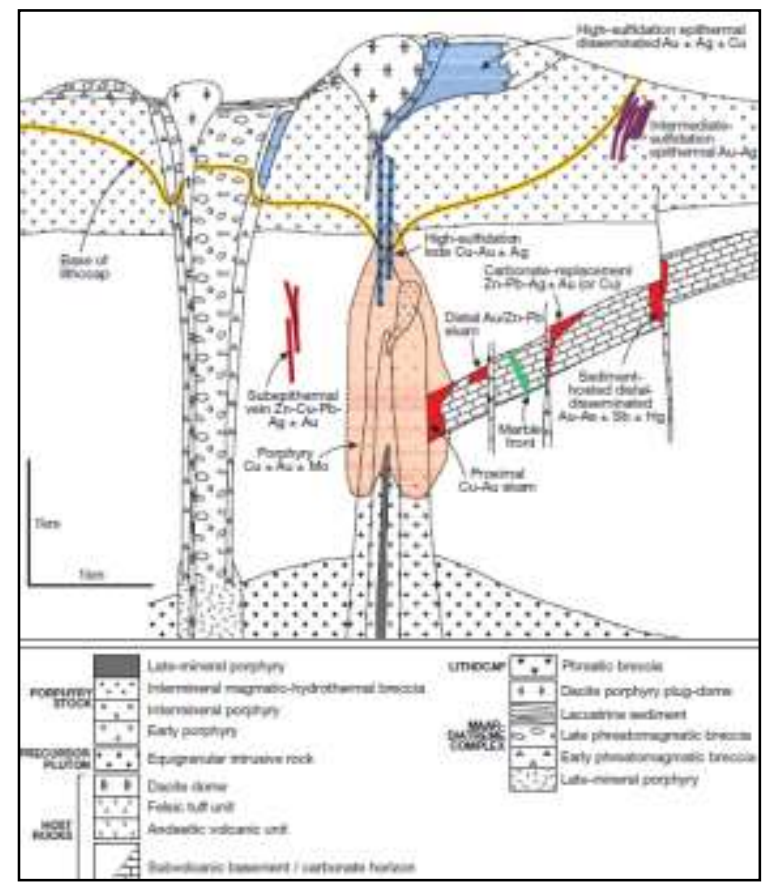

Figure 19. Hydrothermal deposit model related associated with porphyry copper deposits (Sillitoe, 2010)

The weakness of the alteration mineral mapping is the high vegetation index, especially in Merubetiri Mountains which are the National Park complex. So it is quite difficult to capture the mineral spectral image. In addition, the limited interpretation of geology and volcanic centers based on secondary data and morphological observations is interpretive. Although a lot of volcanostratigraphic research has been carried out on active volcanoes, the identification of complex areas of volcanic remnants is still difficult and rarely done due to geological and exogenic processes such as erosion and high weathering rates, especially in Indonesia which has a tropical climate. The determination of the volcanic center using remote sensing has a large gap because it relies on morphological and interpretive observations. It is necessary to make further observations using geophysical data and geological mapping in the field to gain an understanding of the volcanic system that 
exists in the location. The Merubetiri Mountains are a mineralized district with high potential, but very little research exists in this complex. So, it is hoped that further research on the hydrothermal system at this location is expected.

\section{CONCLUSION}

The presence of minerals associated with hydrothermal alteration correlates with volcanic landforms such as stratovolcano, caldera, and volcanic structures in an active hydrothermal system with a spread that is not too wide because it is covered by young volcanic products. The presence of alteration minerals in the Merubetiri Mountains generally correlates with remnants of volcanic activity such as volcanic cones, caldera, and intrusions. Most of the volcanic features found at the study site are caldera setting. Hydrothermal-volcanic systems rarely occur in this caldera arrangement, but occur more frequently in the stratovolcano order. This is reflected in the distribution of alteration minerals that generally occur in these stratovolcanoes both on the summit and volcanic flanks. Hydrothermal systems also develop in areas of volcanic structures formed by the caldera evolution. The main control forces in the Ijen Caldera Complex are northwest-southeast and east-west as well, trending northwest-southeast, north northwest - south southeast, and east-west in the Merubetiri Mountains.

\section{REFERENCES}

Achdan, A., and Bachiri, S., (1993) Peta Geologi Regional Lembar Blambangan, Jawa Timur skala 1:100.000, Pusat Penelitian dan Pengembangan Geologi, Bandung.

Agustiyanto, D. A., and Santosa, S., (1993) Peta Geologi Regional Lembar Situbondo, Jawa skala 1:100.000, Pusat Penelitian dan Pengembangan Geologi, Bandung.
Bronto, S., (2010) "Geologi Gunung Api Purba", Publikasi Khusus Badan Geologi, Kementrian Energi Sumber Daya Mineral, Bandung.

Harrison, R. L., Maryono, A., Norris, M. S., Rohrlach, B. D., Cooke, D. R., Thompson, J. M., dan Thiede, D. S., (2018) "Geochronology of the Tumpangpitu porphyry $\mathrm{Au}-\mathrm{Cu}-\mathrm{Mo}$ and highsulfidation epithermal $\mathrm{Au}-\mathrm{Ag}-\mathrm{Cu}$ deposit: Evidence for pre-and postmineralization diatremes in the Tujuh Bukit district, Southeast Java, Indonesia", Economic Geology, 113(1), pp. 163-192.

Hedenquist, J. W., Izawa, E., Arribas Jr, A., and White, N. C., (1995) "Epithermal gold deposits: styles, characteristics, and exploration", Resource Geology Special Publication, SEG Newsletter, 23, pp. 9-13.

Javhar, A., Chen, X., Bao, A., Jamshed, A., Yunus, M., Jovid, A., and Latipa, T., (2019) "Comparison of multi-resolution optical Landsat-8, Sentinel-2 and radar Sentinel-1 data for automatic lineament extraction: A case study of Alichur area, SE Pamir," Remote Sensing, 11(7), pp. 778.

Jensen, J. R., (2015) Introductory Digital Image Processing: A Remote Sensing Perspective, $4^{\text {th }}$ Ed. United States of America, Pearson Education.

Myaing, Y., Idrus, A., and Titisari, A.D., (2018) "Fluid Inclusion Study of the Tumpangpitu High Sulfidation Epithermal Gold Deposit in Banyuwangi District, East Java, Indonesia", Journal of Geoscience, Engiinering, Environtment, and Technology, 3(1).

Sabins, F., (1999) "Remote sensing for mineral exploration," Ore geology reviews, 14(3-4), pp. 157-183.

Salamba, K. E., Hede, A. N. H., and Heriawan, M. N., (2019) "Identification of alteration zones using a Landsat 8 image of densely vegetated areas of the Wayang Windu Geothermal field, West Java, Indonesia", In IOP Conference Series: Earth and Environmental Science, 254(1), pp. 012004, IOP Publishing.

Sapei, T., Suganda, H., Astadiredja, K. A. S., and Suharsono, (1992) Peta Geologi Regional Lembar Jember, Jawa. Bandung skala 1:100.000, Pusat Penelitian dan Pengembangan Geologi, Bandung.

Scher, S., Williams-Jones, A. E., and Williams-Jones, G., (2013) "Fumarolic activity, acid-sulfate alteration, and high sulfidation epithermal precious metal mineralization in the crater of Kawah Ijen Volcano, Java, Indonesia", Economic Geology, 108(5), pp. 1099-1118.

Setijadji, L. D., Kajino, S., Imai, A., and Watanabe, K., (2006) "Cenozoic island arc magmatism in Java Island (Sunda Arc, Indonesia): Clues on relationships between geodynamics of volcanic centers and ore mineralization", Resource Geology, 56(3), pp. 267-292. 
Sidarto, T.S., and Sudana, D., (1993) Peta Geologi Regional Lembar Banyuwangi, Jawa. Bandung skala 1:100.000, Pusat Penelitian dan Pengembangan Geologi, Bandung.

Sigurdsson, H., (2000) Encyclopedia of Vulcanoes, Academic Press, San Diego.

Sillitoe, R. H., and Bonham, H. F., (1984) "Volcanic landforms and ore deposits", Economic Geology, 79(6), pp. 1286-1298.
Sillitoe, R. H., (2010) "Porphyry copper systems", Economic geology, 105(1), pp. 3-41.

Stern, R. J., Magmatism at Convergent Plate Boundaries, Springer, 2015.

Stimac, J., Goff, F., and Goff, C. J., (2015 ) "Intrusionrelated geothermal systems", In The Encyclopedia of Volcanoes, pp. 799-822. 